\section{Scientific journal}

\section{PHYSICAL AND MATHEMATICAL EDUCATION}

Has been issued since 2013 .

Науковий журнал

ФІЗИКО-МАТЕМАТИЧНА ОСВІТА

Видається з 2013.
ISSN 2413-158X (online)

ISSN 2413-1571 (print)

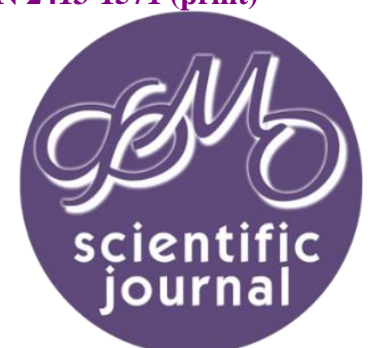

Сороко Н.В. Функції доповненої реальності для підтримки STEAM освіти в закладах загальної освіти. Фізикоматематична освіта. 2021. Випуск 3(29). С. 24-30.

Soroko N. The augmented reality functions to support the STEAM education at general education institutions. Physical and Mathematical Education. 2021. Issue 3(29). P. 24-30.

DOI 10.31110/2413-1571-2021-029-3-004

UDC 373.3/.5.091-026.911:004.946

N. Soroko

Institute of Information Technologies and Learning Tools of NAES of Ukraine, Ukraine nvsoroko@gmail.com

ORCID: 0000-0002-9189-6564

\title{
THE AUGMENTED REALITY FUNCTIONS TO SUPPORT THE STEAM EDUCATION AT GENERAL EDUCATION INSTITUTIONS
}

\section{ABSTRACT}

The paper considers immersive technologies in education. Augmented reality classifications are provided depending on the data presentation methods, the type of AR devices, according to the type of information provided by the augmented reality, and the areas of use. The importance of augmented reality in education, in particular for the support and development of STEAM education in school, is determined. An example of a STEAM project for a secondary school using augmented reality is given.

Formulation of the problem. The need for research due to various factors impact on education, namely increased requirements for competitive youth, pandemic caused COVID-19, increasing the role of distance and online learning, digitalization of various human activities, giving special importance to digital literacy, inquiry-based science education, project-based learning, challenge-based learning, etc. A significant problem arises in the process of organizing practical and laboratory classes in non-humanities, where the formation of competencies takes place in the process of using laboratory equipment and inter-action with technical facilities. Therefore, the main task of our study is to replace real laboratory equipment with virtual, which is implemented by virtual (VR) and augmented reality $(A R)$ and is one of the possible approaches in terms of distance learning, STEAM education approach and quarantine.

Materials and methods. To achieve the purpose of our study we used the following methods: a systematic and comparative analysis of pedagogical, psychological, philosophical, sociological findings, methodological and specialized literature; analysis of the pedagogical experience of using the AR for STEAM approach in school; synthesis and generalization to formulate the main points of the study; interviews and questionnaires of teachers about their understanding and attitude to augmented reality as a means of supporting STEAM education in school; interpretation of the research results.

Results. Teachers were interviewed about their attitudes and understanding of AR to support STEAM education and to identify the main augmented reality functions in conducting STEAM projects in schools. Conclusions are made on the attitude of teachers to the use of augmented reality to support and develop STEAM education and the main augmented reality functions, which teachers consider the most important for students to implement STEAM projects.

Conclusions. AR applications can enhance the learning process, learning motivation and effectiveness; help teachers to overlay information, visuals, and different forms of content on an ordinary chalkboard, providing contextual and relevant results, to enhance learning; improve student performance, help focus the user's attention on specific tasks.

AR bring significant specifics to the teachers' professional activities and student learning, to the transformation of the content of education. AR provide the formation and development of a new information method of presentation and assimilation of material, are high-tech didactic tools.

Our further research is the creation of algorithms for the use of AR for lessons and projects using the STEAM approach, which will improve the quality of education at general education institutions.

KEY WORDS: immersive technologies, augmented reality, STEAM education, STEAM approach, STEM education, general education institution.

\section{INTRODUCTION}

The rapid development of the information society significantly contributes to the deepening of research and the emergence of new areas of knowledge and technology, such as information and communication technologies (ICT), nano- and biotechnology, and others. This causes a change of priorities in education. Important in the educational process of a secondary school is the orientation of teachers to the competence approach, the development of students' sense of initiative and entrepreneurship, creative thinking, the ability to turn ideas into life through creativity, innovation and others. One of the main 
trends in the modernization of education is the focus on the so-called "STEM" education, which involves integration between the disciplines of natural sciences, technological sciences, engineering and mathematics. The urgency of this area is explained by the significant demand of the world labor market for specialists who will provide scientific and technological progress (Soroko, 2020). The STEAM ("A" - art) education approach help students discover how the arts are an integral part of processes and products that involve science, technology, engineering, and mathematics. The arts can also help increase engagement since students can connect artistic mediums that they enjoy (for example, music, history, literature, visual arts and other) with more technical projects that may seem daunting at first, such as building an app or programming a robots. Such approach able to combine the familiar with the unfamiliar, acquiring new skills and discovering the world of artistic innovation.

In the context of the pandemic caused by COVID-19, distance learning with the help of ICT becomes important for the school learning process. In distance learning, the teaching of theoretical material is sufficiently well implemented by simple means of audio or video broadcasts, placement of text materials or presentations. A significant problem arises in the process of organizing practical and laboratory classes in non-humanities, where the formation of competencies takes place in the process of using laboratory equipment and inter-action with technical facilities. Therefore, the main task of our study is to replace real laboratory equipment with virtual, which is implemented by virtual (VR) and augmented reality (AR) and is one of the possible approaches in terms of distance learning, STEAM education approach and quarantine.

\section{THEORETICAL BACKGROUNDS}

VR is a digital environment where elements are displayed to a user via different interfaces for the respective senses, and in which the participant is immersed in an artificially created world, which may or may not mimic the properties of a real environment, either existing or fictional, but which may also exceed the bounds of physical reality by creating a world in which the physical laws governing gravity, time and material properties no longer hold (Craig, Sherman, \& Will, 2009).

Tepe T., Kaleci D., Tüzün H. define VR as a three-dimensional simulation environment where users can experience closeness to a real-world experience in an artificial world developed with a variety of visualization devices and equipment, as well as interacting with other objects (Tepe T., Kaleci D., Tüzün H., 2018).

Virtual reality should not be confused with augmented reality. Their fundamental difference in that the virtual constructs a new artificial world, and augmented reality only introduces certain artificial elements into the perception of the real world.

We should pay attention to the idea "Reality Virtuality Continuum" by Paul Milgram (Milgram, et al., 1995). It spans from a completely real environment to a completely virtual environment. The span between the two extremities is a range called "mixed reality" (MR), which includes the virtual reality (VR) and the augmented reality (AR), while technology enabling immersion into mixed realities is commonly referred to as "immersive technology" (Mihelj, et al., 2014).

We provide a comparative description of VR and AR to understand, how they differ from each other:

- VR constructs a new artificial world, and AR only introduces some artificial elements into the perception of the real world;

- VR is a reflection of the real world around us, artificially created by technical tools and presented in digital form by specialized helmets and goggles; AR is usually implemented using applications for smartphones and tablets, augmented reality glasses, stationary screens, projection devices and other technologies.

Researchers determine that augmented reality is more promising for its use in various spheres of human activity than virtual reality.

In 2019, the Perkins Coie conducted a survey on the attitude of citizens to the use of augmented reality (Augmented and Virtual Reality survey report, 2019).

The vast majority - 70\% - of respondents (the survey was completed by 200 respondents) said in 2019 they anticipate the AR market to surpass the VR market in revenue. When asked when the AR market will surpass the VR market, $81 \%$ of respondents predicted it would happen within five years (Augmented and Virtual Reality survey report, 2019).

In January and February 2020, 191 professionals completed the 2020 Augmented Reality and Virtual Reality Survey conducted by Perkins Coie LLP, the XR Association, and Boost VC (Augmented and Virtual Reality survey report, 2020). Among the respondents were: C-Suite (48\%); Engineer / Producer (14\%); Marketing / Business Development (12\%); Consultant / Lawyer (5\%); Investor (4\%); Other (17\%).

The situation regarding the attitude of respondents to augmented and virtual realities has not changed compared to 2019: 76\% of respondents said they anticipate the AR market to surpass the VR market in revenue (Fig. 1).

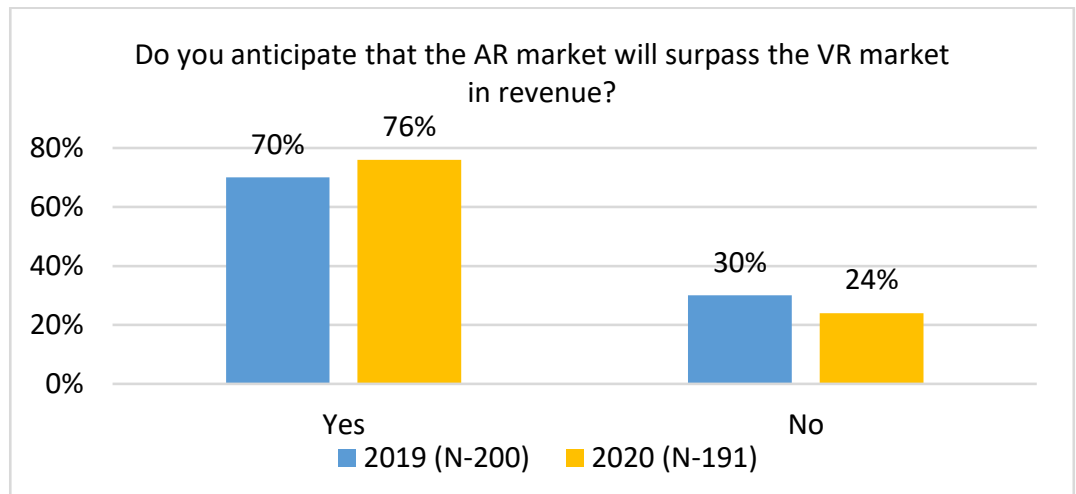

Fig. 1. Diagram of presenting the results of respondents' answers to questions «Do you anticipate that the AR market will surpass the VR market in revenue?» (2019 \& 2020) 
The arguments for such respondents' answers (Fig. 1) were provided by the respondents in the answers to the questions "Which of the following factors are most responsible in terms of the AR market surpassing the VR market? (Select all that apply)»:

- Cost (e.g., creating good AR apps or adding AR features to an existing app is cheaper than producing good VR apps and content) $-57 \%$;

- Accessibility of AR - 52\%;

- Safety - 45\%;

- Easier and more intuitive experiences offered by AR - 41\%;

- Higher investment by businesses in AR technology - 33\%;

- Scalability of AR - 30\%;

- More real-world applications and tangible benefits for AR - 30\%;

- Greater presence of AR-compatible applications and software - 27\%;

- Higher preference for AR by consumers - 24\%;

- No requirement of additional gear for AR $-9 \%$.

Due to the big variety of applications related to augmented reality, it can be distinguished the following types:

1. According to the representation method (Fig. 2):

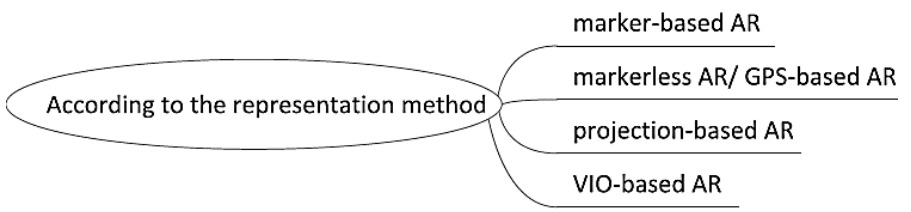

Fig. 2. Types of AR according to the representation method

- marker-based AR, that uses a camera and a special passive visual marker, such as a QR code (quick response code), which shows the programmed result only when the sensor reads it (Jack C.P. Cheng, 2017);

- markerless AR, that uses Global Positioning System (GPS); the most common uses are to mark destinations, search for the right number, such as a café or office, or in location-oriented apps (Jack C.P. Cheng, 2017);

- projection-based AR is a video projection technique, which can extend and reinforce visual data by throwing images on the surface of 3D objects or space; this belongs to Spatial Augmented Reality in a broad sense (Lee, Jaewoon, 2015)

- VIO-based AR (Visual Inertial Odometry, VIO) is a technology that helps track position and navigate in space with sensors and a camera; this makes it possible to create an accurate 3D model of the space around the device, update it in real time, determine its position in it, transfer this data to all applications and apply additional layers on top of it (X. Li, 2020).

2. According to the type of AR devices (Pratibha Jha, Sapna Yadav, 2019) (Fig. 3):

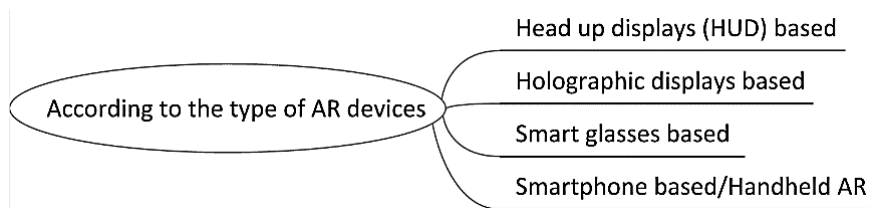

Fig. 3. Types of AR according to the type of AR devices

- Head up displays (HUD) based, that contains such components as a projector unit, a viewing glass (combiner) and a computer (symbol generator);

- Holographic displays based, that can realize the functions of an optical combiner, a see-through eye piece or a beam expander (Y. Li, P. Zhou and Y. Su, 2019);

- Smart glasses based are defined as wearable AR devices that are worn like regular glasses and merge virtual information with physical information in a user's view field (Ro, Young, 2017);

- Smartphone based/Handheld AR, that is allowing users to interact with the virtual object in augmented scene in handheld devices (Chowdhury, Shahan, 2013).

3. According to the type of information provides by augmented reality (Fig. 4)

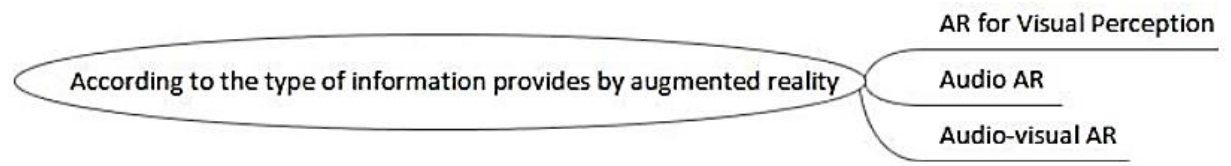

Fig. 4. Types of AR according to the type of information provides by augmented reality

- AR for Visual Perception, that to provide visual images based on visual perception of information;

- Audio AR, that is for audio perception focused on auditory perception and are usually used in navigation (Hannes Gamper, 2014);

- Audio-visual AR, that is a technology that combines audio and video expressions (Edmund Ng Giap Weng, 2013).

4. According to the using fields (R. Silva, 2004) AR can be for entertainment and news business, education, medicine, engineering and manufacturing, military training, engineering design, tourism, shopping and other (Fig. 5). 


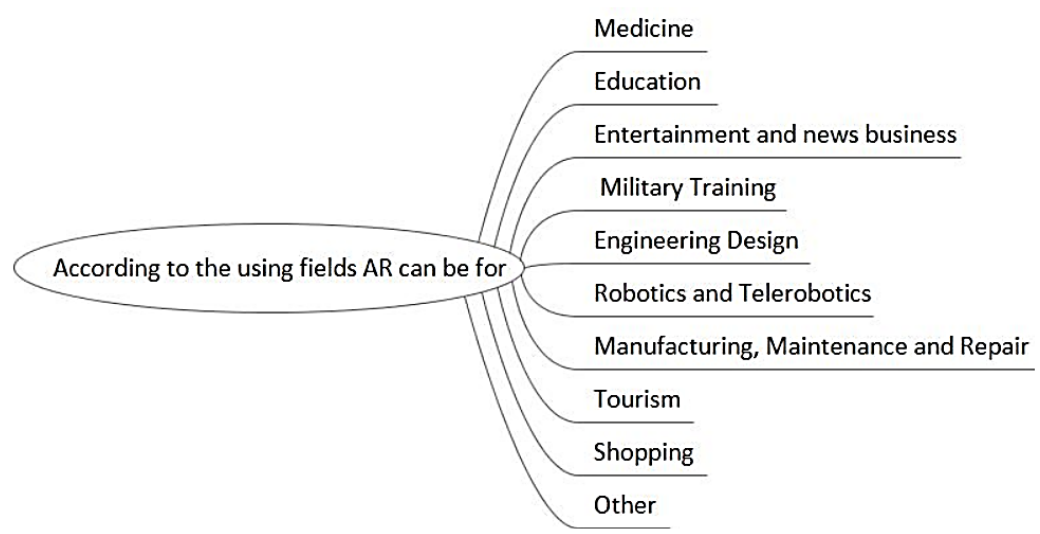

Fig. 5. Types of AR according to the using fields

We should be noted that augmented reality is becoming relevant in education (Augmented and Virtual Reality survey report, 2020).

Mustafa Sirakaya and Didem Alsancak Sirakaya (Mustafa Sirakaya, Didem Alsancak Sirakaya, 2018) conducted research on scientific publications related to the use of augmented reality in various fields of science, and determined that:

- AR is often used in biology $(19,8 \%)$, engineering $(12,8 \%)$ and medical training $(11,6 \%)$;

- AR technology is also employed in fields such as language education $(5,8 \%)$, special education $(4,7 \%)$, preschool education $(3,5 \%)$, history education $(2,3 \%)$ and astronomy education $(2,3 \%)$.

Scientists point out that AR is especially important for to implementation STEAM approach in education (Jesionkowska, Joanna, 2020). AR application in STEAM education brings lessons and textbooks to life by combining video, photos, and audio in an interactive platform (Nawarat Wittayakhom \& Pallop Piriyasurawong, 2020). This provides students with an engaging way to learn that can make complex subjects and topics easier to grasp and understand makes teaching easier where teachers no longer need to explain complex concepts.

The purpose of the article is to analyze the use of augmented reality to support of STEAM education at school and highlighting the main functions of augmented reality for this.

\section{RESEARCH METHODOLOGY}

To achieve the purpose of our study we were used the following methods: a systematic and comparative analysis of pedagogical, psychological, philosophical, sociological works, methodological and specialized literature; analysis of the pedagogical experience of using the AR for STEAM approach in school; synthesis and generalization to formulate the main points of the study; interviews and questionnaires of teachers about their understanding and attitude to augmented reality as a means of supporting STEAM education in school; interpretation of the research results.

\section{RESULTS}

Once the surveys distributed in online format (Google Forms) among 24 teachers from a Primary Education school and 70 teachers from Secondary General Education two schools (Levels I-III N1 in Brovary (Ukraine) and at Semipolkivskyi Secondary School of the 1st-3rd Grade (Ukraine)), the data were collected and a statistical study was carried out among all the teachers surveyed.

Table 1

The results of teachers' survey on their attitudes and understanding AR for STEAM education

\begin{tabular}{lccccc}
\hline & $\begin{array}{c}\text { Strongly } \\
\text { disagree }(\%)\end{array}$ & $\begin{array}{c}\text { Disagree } \\
(\%)\end{array}$ & $\begin{array}{c}\text { Neither agree nor } \\
\text { disagree }(\%)\end{array}$ & $\begin{array}{c}\text { Agree } \\
(\%)\end{array}$ & $\begin{array}{c}\text { Strongly agree } \\
(\%)\end{array}$ \\
\hline $\begin{array}{l}\text { I have a clear understanding of } \\
\text { what AR is and how I can it }\end{array}$ & 8,0 & 27,0 & 27,0 & 34,0 & 4,0 \\
integrated with STEAM & & & & & \\
education in my class \\
$\begin{array}{l}\text { I have heard colleagues talking } \\
\text { about AR for STEAM education } \\
\text { I have talked with colleagues } \\
\text { about AR for STEAM education }\end{array}$
\end{tabular}

According to the survey results on teachers' understanding AR to be provided for supporting the STEAM-oriented approach in general school teaching process, the teachers are interested in using AR in STEAM education:

"I have a clear understanding of what AR is and how I can integrate it with STEAM education in my class»: Neither agree nor disagree $-27 \%$; Agree $-27 \%$; Strongly agree -4 ; 
"I have heard colleagues talking about AR in STEAM education»: Neither agree nor disagree - 32\%; Agree - 36,6\%; Strongly agree $-7.4 \%$;

«I have talked with colleagues about AR in STEAM education»: Neither agree nor disagree $-32 \%$; Agree - 33\%;

«I can use teaching approaches with VR that foster integrated STEAM education»: Neither agree nor disagree $-25.7 \%$ ); Agree $-30,7 \%$.

We invited teachers to conduct a training project that can cover all STEAM disciplines, the use of ICT and especially AR. The project was developed within the MOOC "Aerospace in Class» coordinated by European Schoolnet (https://www.europeanschoolnetacademy.eu/courses). The name of the project is «Future of Space».

In Table 2, we offer the approximate plan of realization the Project «Future of Space», which displays and supports inquiry-based science education, project-based learning.

The approximate plan of realization the Project «Future of Space»

\begin{tabular}{|c|c|}
\hline $\begin{array}{l}\text { The components of the } \\
\text { project }\end{array}$ & Short description \\
\hline $\begin{array}{l}\text { Summary of project «Future } \\
\text { of Space» }\end{array}$ & $\begin{array}{l}\text { 1. In this deliberation, students will explore current issues pertaining to the space program } \\
\text { and form opinions regarding priorities for space travel and exploration, and private } \\
\text { partnership in the space program. } \\
\text { 2. Space exploration studies can sometimes produce unintended consequences. One of them } \\
\text { is fatal accidents and the other is space pollution. Space pollution is caused by the remains of } \\
\text { satellites, telescopes, space laboratories and fragments that have been thrown from Earth } \\
\text { into space. }\end{array}$ \\
\hline Subjects & Science, mathematics, IT, visual arts \\
\hline Topic & Clouds in the sky, life in space, space costumes, making rocket and more \\
\hline $\begin{array}{l}\text { Questions for brainstorming } \\
\text { and discussion }\end{array}$ & $\begin{array}{l}\text { How would be like our clothes if we lived in space? } \\
\text { What are the requirements for transport to be used in space? } \\
\text { What problems can the ecology of space have if people actively use it? }\end{array}$ \\
\hline Age range of students & $\begin{array}{l}7-11 \text { age (there is no physics or chemistry in the curricula); } \\
12-14 \text { age (within the curricula of subjects); } \\
14-16 \text { age (Consolidation); } \\
16-18 \text { age (Deepening) }\end{array}$ \\
\hline Preparation time & 150 minutes \\
\hline Teaching time & $\begin{array}{l}30 \text { minutes - space suit design, } 30 \text { minutes - space cap, } 30 \text { minutes - making rocket (solving } \\
\text { experimental problems and tasks), } 30 \text { minutes - planetary cards }\end{array}$ \\
\hline Online teaching material & $\begin{array}{l}\text { Padlet, Kahoot, Canva, etc.; } \\
\text { Python: https://www.programiz.com/python-programming/online-compiler/ (to write } \\
\text { programs for solving problems); } \\
\text { Air-breathing rocket engines: the future of space flight: https://physicsworld.com/a/air- } \\
\text { breathing-rocket-engines-the-future-of-space-flight/; } \\
\text { 4d space cards }\end{array}$ \\
\hline Offline teaching material & Surgical suit, mask, paper, glue, colored printouts, etc. \\
\hline$A R$ & $\begin{array}{l}\text { GeoGebra AR, AR Geometry Hololens 2, AR Chemistry Mobile App, Merge EDU (Merge Cube), } \\
\text { CoSpaces Edu application, Planets AR, Skyscrapers AR, }\end{array}$ \\
\hline Results & Presentations of problem solving and models of space ships or clothes for Space \\
\hline
\end{tabular}

Within the theme of this project, STEAM subject teachers had to develop their tasks for students of different levels of education, who may be close to the problem of the project and try out the proposed AR tools or offer their own tools (for example, GeoGebra AR, AR Geometry Hololens 2, AR Chemistry Mobile App, Merge EDU, CoSpaces Edu application, etc).

After conducting this project in two schools (Levels I-III N1 in Brovary (Ukraine) and at Semipolkivskyi Secondary School of the 1st-3rd Grade (Ukraine), 2021), we offered to teachers (68 secondary school teachers) determine what features augmented reality tools have to support the STEAM-oriented approach in general school (Table 3).

Respondents were asked to evaluate the proposed augmented reality functions to support the STEAM education at school by using a five Likert scale ranging from very undesirable (1) to very desirable (5).

Table 3 demonstrates that teachers especially distinguish such augmented reality functions to support the STEAM education at school, as:

- Learning function that affects the students learning needs and provides assistance in solving educational problems;

- Function of models' visualization for students' perception of educational material;

- Motivational function that influences the increase of students' interest in learning;

- Didactic function, which provides for the appropriate use of $A R$ to facilitate the implementation of the educational process in accordance with the curricula of subjects.

In addition to these features, we have to add, that an important function of augmented reality is to provide context awareness, which is the ability to provide information appropriate to the situation. The motivating strength of context awareness is precision: it enables the correct information, and only the correct information, to be displayed at the appropriate time. 
The survey results about teachers' attitudes to the proposed augmented reality functions to support the STEAM education at school

\begin{tabular}{|c|c|}
\hline The augmented reality functions to support the steam education at school & Mean values \\
\hline $\begin{array}{l}\text { Learning function that affects the students learning needs and provides assistance in solving educational } \\
\text { problems }\end{array}$ & 4,9 \\
\hline Function of models' visualization for students' perception of educational material & 4,9 \\
\hline Motivational function that influences the increase of students' interest in learning & 4,9 \\
\hline $\begin{array}{l}\text { Learning mobility, which provides the possibility of independent learning material by students, without } \\
\text { explanations and support of the teacher }\end{array}$ & 2,7 \\
\hline $\begin{array}{l}\text { Technological function, which provides communication between the participants of the educational process, } \\
\text { support for laboratory, practical, control works and their evaluation, access to various data sources } \\
\text { (databases, conferences, electronic libraries, etc.) }\end{array}$ & 3,7 \\
\hline $\begin{array}{l}\text { Psychological function that helps to motivate the subjects of the educational process (teachers; students; } \\
\text { parents; specialists in certain fields of education, science, business, etc.) To participate in educational } \\
\text { projects in the fields of steam; promotes the formation of students' responsible behaviours in the } \\
\text { implementation of these projects and the development of professional competence of teachers to } \\
\text { encourage the subjects of the educational process to participate in them }\end{array}$ & 3,5 \\
\hline $\begin{array}{l}\text { Didactic function, which provides for the appropriate use of ar to facilitate the implementation of the } \\
\text { educational process in accordance with the curricula of subjects }\end{array}$ & 4,5 \\
\hline Total $(n=68)$ & \\
\hline
\end{tabular}

\section{CONCLUSIONS}

AR applications can enhance the learning process, learning motivation and effectiveness; help teachers to overlay information, visuals, and different forms of content on an ordinary chalkboard, providing contextual and relevant results, to enhance learning; improve student performance, help focus the user's attention on specific tasks.

AR have a number of characteristics that become advantages over other types of visualization to support STEAM education:

- ensuring interaction with the object on an intuitive level;

- providing real-time information;

- easy to use (no special skills and knowledge required for viewing);

- providing an opportunity to show what cannot be imagined in the usual ways;

- providing opportunities to easily change the parameters of the object through the interface of a special application;

- providing opportunities to adapt virtual objects to the real environment.

Thus, AR bring significant specifics to the teachers' professional activities and student learning, to the transformation of the content of education. AR provide the formation and development of a new information method of presentation and assimilation of material, are high-tech didactic tools.

Our further research is the creation of algorithms for the use of AR for lessons and projects using the STEAM approach, which will improve the quality of education at school.

1. Augmented and Virtual reality survey report (2019). Presented by PERKINS COIE. URL: https://www.perkinscoie.com/images/content/2/1/v4/218679/2019-VR-AR-Survey-Digital-v1.pdf. (Last accessed: 15.05.2021).

2. Augmented and Virtual reality survey report (2020). Presented by PERKINS COIE. URL: https://www.perkinscoie.com/images/content/2/3/v4/231654/2020-AR-VR-Survey-v3.pdf. (Last accessed: 19.05.2021).

3. Chowdhury, Shahan \& Arshad, Haslina \& Parhizkar, Behrang \& Obeidy, Waqas. (2013). Handheld Augmented Reality Interaction Technique.(8237. pp. 418-426). DOI: 10.1007/978-3-319-02958-0_38.

4. Craig, A. B., Sherman, W. R., \& Will, J. D. (2009). Developing Virtual Reality Applications -Foundations of Effective Design. Multiple: Morgan Kaufmann Publishers.

5. Edmund Ng Giap Weng, Md. Abdullah-Al-Jubair, Shahren Ahmad Zaidi Adruce, Oon Yin Bee (2013). Graphics, Audio-visuals and Interaction (GAl) based handheld augmented reality system. The 9th International Conference on Cognitive Science. Procedia - Social and Behavioral Sciences 97. (pp.745-752). Published by Elsevier Ltd. DOI: 10.1016/j.sbspro.2013.10.296

6. Hannes Gamper (2014). Enabling technologies for audio augmented reality systems. Aalto University publication series doctoral dissertations. URL: https://core.ac.uk/download/pdf/80711759.pdf. (Last accessed: 19.05.2021).

7. Jack C.P. Cheng, Keyu Chen, and Weiwei Chen (2017). Comparison of marker-based AR and markerless AR: A case study on indoor decoration system. [Proc. Lean \& Computing in Construction Congress (LC3)] (Vol. 2) (CONVR), Heraklion, Greece. DOI: 10.24928/JC3-2017/0231.

8. Jesionkowska, Joanna; Wild, Fridolin; Deval, Yann (2020). Active Learning Augmented Reality for STEAM Education - A Case Study. Educ. Sci. 10, no. 8: 198. https://doi.org/10.3390/educsci10080198. 
9. Lee, Jaewoon; Kim, Yeonjin; Heo, Myeong-Hyeon; Kim, Dongho; Shin, Byeong-Seok (2015). Real-Time Projection-Based Augmented Reality System for Dynamic Objects in the Performing Arts. Symmetry (7(1), pp. 182-192). https://doi.org/10.3390/sym7010182

10. Mihelj, Matjaž, Novak, Domen, Beguš, S. (2014). Virtual Reality Technology and Applications. DOI:10.1007/978-94-007-6910-6

11. Milgram, P., Takemura, H., Utsumi, A. \& Kishino, F. (1995). Augmented Reality: A class of displays on the reality-virtuality continuum. s.l., s.n. (pp. 282-292).

12. Nawarat Wittayakhom \& Pallop Piriyasurawong (2020). Learning Management STEAM Model on Massive Open Online Courses Using Augmented Reality to Enhance Creativity and Innovation. [Higher Education Studies] (Vol. 10, No. 4.) URL: https://files.eric.ed.gov/fulltext/EJ1274957.pdf (Last accessed: 19.05.2021).

13. Pratibha Jha, Sapna Yadav (2019). Virtual and Augmented Reality: An Overview. International Journal of Trend in Scientific Research and Development (IJTSRD) (Volume: 3. Issue: 3.) URL: www.ijtsrd.com (Last accessed: 19.05.2021).

14. R. Silva, J. C. Oliveira, G. A. Giraldi (2004). Introduction to Augmented Reality. National Laboratory for Scientific Computation. URL: https://www.Incc.br/ jauvane/papers/RelatorioTecnicoLNCC-2503.pdf. (Last accessed: 25.05.2021).

15. Ro, Young \& Brem, Alexander \& Rauschnabel, Philipp. (2017). Augmented Reality Smart Glasses: Definition, Concepts and Impact on Firm Value Creation. DOI: 10.1007/978-3-319-64027-3_12.

16. Soroko N. (2020). Methodology for Teachers' Digital Competence Developing Through the Use of the STEAM-oriented Learning Environment. ICTERI-2020. Part VI: 4th International Workshop Methods, Resources and Technologies for Open Learning and Research (MROL 2020). (pp. 1260-1271). URL: http://ceur-ws.org/Vol-2732/20201260.pdf. (Last accessed: 19.05.2021).

17. Tepe T., Kaleci D., Tüzün H. (2018) Virtual Reality Applications in Education. In: Lee N. (eds) Encyclopedia of Computer Graphics and Games. Springer, Cham. URL: https://doi.org/10.1007/978-3-319-08234-9_166-1 (Last accessed: 21.05.2021).

18. X. Li, Y. Tian, F. Zhang, S. Quan and Y. Xu (2020). Object Detection in the Context of Mobile Augmented Reality. 2020 IEEE International Symposium on Mixed and Augmented Reality (ISMAR). (pp. 156-163). DOI: 10.1109/ISMAR50242.2020.00037.

19. Y. Li, P. Zhou and Y. Su (2019). Holographic Displays for AR Applications. IEEE International Conference on Consumer Electronics (ICCE). 1-2. DOI: 10.1109/ICCE.2019.8662088.

20. Mustafa Sirakaya, Didem Alsancak Sirakaya (2018). Trends in Educational Augmented Reality Studies: A Systematic Review. URL: http://dx.doi.org/10.17220/mojet.2018.04.005.

\section{ФУНКЦІї ДОПОВНЕНОї РЕАЛЬНОСТІ ДЛЯ ПІДТРИМКИ SТЕАМ ОСВІТИ В ЗАКЛАДАХ ЗАГАЛЬНОЇ ОСВІТИ Н.В. Сороко}

Інститут інформачійних технологій і засобів навчання НАПн України, Україна

Анотація. У роботі розглянуті імерсивні технології в освіті. Надані класифікації доповненої реальності (АR) залежно від методів представлення даних, за типом AR-пристроїв, відповідно до типу інформації, що надає доповнена реальність, та за галузями використання. Визначено значення доповненої реальності в освіті, зокрема для підтримки та розвитку STEAMосвіти в школі. Наведений приклад STEAM-проєкту для закладу загальної освіти із використанням доповненої реальності.

Формулювання проблеми. Необхідність дослідження обумовлена різними чинниками впливу на освіту, а саме: підвищенням вимог до конкурентноспроможної молоді, пандемія, спричинена COVID-19, підвищення ролі дистанційного та онлайн навчання, цифровізація різних галузей людської діяльності, надання особливого значення цифровій грамотності особистості, розвиток проєктного і проблемно-орієнтованого навчання та ін. У дистанційному навчанні викладання теоретичного матеріалу досить добре реалізується за допомогою простих засобів аудіо- чи відеотрансляції, розміщення текстових матеріалів або презентацій. Значна проблема виникає в процесі організації практичних та лабораторних занять з негуманітарних дисциплін, де формування вмінь і навичок відбувається в процесі використання лабораторного обладнання та взаємодії з технічними засобами. Тому основним завданням нашого дослідження є заміна реального лабораторного обладнання на віртуальне, яке реалізоване через використання доповненої реальності.

Матеріали і методи. Для досягнення мети дослідження нами були використані наступні методи: систематичний та порівняльний аналіз педагогічних, психологічних, філософських, соціологічних робіт, методичної та спеціалізованої літератури; аналіз педагогічного досвіду використання AR для підходу STEAM у школі; синтез та узагальнення для формулювання основних моментів дослідження; інтерв'ю та анкетування вчителів про їх розуміння та ставлення до доповненої реальності як засобу підтримки навчання STEAM у школі; інтерпретація результатів дослідження.

Результати. Проведено опитування вчителів щодо їхнього ставлення і розуміння AR для підтримки STEAM освіти та щодо визначення основних функцій доповненої реальності при проведенні STEAM-проєктів у школі. Сформульовано висновки щодо ставлення вчителів до використання доповненої реальності для підтримки і розвитку STEAM освіти та основних функцій доповненої реальності, які вчителі вважають найбільш важливими для здійснення учнями STEAM проєктів.

Висновки. Додатки AR можуть покращити процес навчання, мотивацію та ефективність навчання; допомогти викладачам подавати інформацію учням, візуальні зображення та різні форми вмісту на звичайну дошку, забезпечуючи контекстуальні та відповідні результати для покращення навчання; покращити навчальну успішність учнів, допомогти їм зосередити увагу на конкретних завданнях та об'єктах.

$A R$ вносять значну специфіку до професійної діяльності вчителів та навчання учнів, до трансформації змісту освіти. АR забезпечують формування та розробку нового інформачійного методу викладу та засвоєння матеріалу, $\epsilon$ високотехнологічними дидактичними інструментами.

Наші подальші дослідження полягають у створенні алгоритмів використання доповненої реальності для уроків та проєктів із використанням підходу STEAM, що покращить якість навчання в школі.

Ключові слова: імерсивні технології, доповнена реальність, STEAM освіта, STEAM підхід, STEM освіта, заклад загальної освіти.

\section{$(\mathrm{CC}) \mathrm{BY}-\mathrm{NC}-\mathrm{SA}$}

This work is licensed under Creative Commons Attribution-NonCommercial-ShareAlike 4.0 International License. 